\title{
Foraminiferal evidence for the East Greenland Current during the Oligocene
}

\section{K. Birkenmajer and A. Jednorowska}

This note summarises results of a microfaunal investigation of nine samples collected in 1971 from the Eocene-Oligocene Krabbedalen Formation, Scoresby Sund, central East Greenland. Six of the samples were taken from a continuous section at Krabbedalen and the remaining three from poor, isolated exposures $0.5 \mathrm{~km}$ east and $2.5 \mathrm{~km}$ south of Krabbedalen, and $4 \mathrm{~km}$ south of Søstrene (Birkenmajer, 1972, fig. 13).

The microfauna includes 37 foraminiferal species, predominantly arenaceous benthos ( 29 species), with single specimens of calcareous benthos ( 7 species) and one specimen of calcareous plankton.

\section{Geological summary}

Small down-faulted outliers of Eocene-Oligocene sediments post-dating Early Tertiary tholeiitic flood basalts with sediment intercalations (Blosseville Group) crop out along the Blosseville Kyst at Kap Dalton and Savoia Halvø (fig. 20). At Savoia Halvø the post-basaltic sediments rest directly on the highest basalt flow which is strongly weathered in a zone up to $11 \mathrm{~m}$ thick and followed by a thin layer $(1.5 \mathrm{~m})$ of fossil soil. The succeeding Bopladsdalen Formation includes the basal conglomerate (up to $2 \mathrm{~m}$ thick) consisting of very well-rounded basalt pebbles in poor, feebly cemented basalt detritus, sometimes with mollusc-shell detritus and carbonised wood, which is followed by yellow-weathered, flaggy sandstones with shallow-marine and brackish molluscs, with pieces of wood with Teredo borings and with scattered basalt pebbles (Cyrena beds of Hassan, 1953). The formation represents a wedge of sediment thickest at the type locality $(80 \mathrm{~m})$ which disappears toward the south at a distance of barely $3 \mathrm{~km}$ (Birkenmajer, 1972).

The Krabbedalen Formation consists of alternating grey to yellowish marly siltstones and hard calcareous siltstones with comparatively rich shallow-marine molluscs and crabs (Coeloma beds of Hassan, 1953), often with single pebbles of basalt or other rocks (Birkenmajer, 1972). The unit conformably overlies the Bopladsdalen Formation at the type locality, but to the south of Krabbedalen it comes directly in contact with the basalts of the Blosseville Group. A hiatus between the two formations is thus suggested, as in the Kap Dalton area (fig. 20; Soper \& Costa, 1976).

\section{Age of the microfauna}

The presence of Globigerina ampliapertura Bolli in material from the middle part of the Krabbedalen section ( $138 \mathrm{~m}$ above sea level) suggests a latest Eocene - Lower Oligocene age for the higher part of the Krabbedalen Formation. Reophax tappuensis Asano, so far reported only from the Oligocene, occurs close to the top of the section (145 $\mathrm{m}$ above sea level). These forms confirm Hassan's (1953) probably Lower Oligocene age of the Krabbedalen Formation (Coeloma beds), based on the comparatively rich mollusc and crab fauna. 


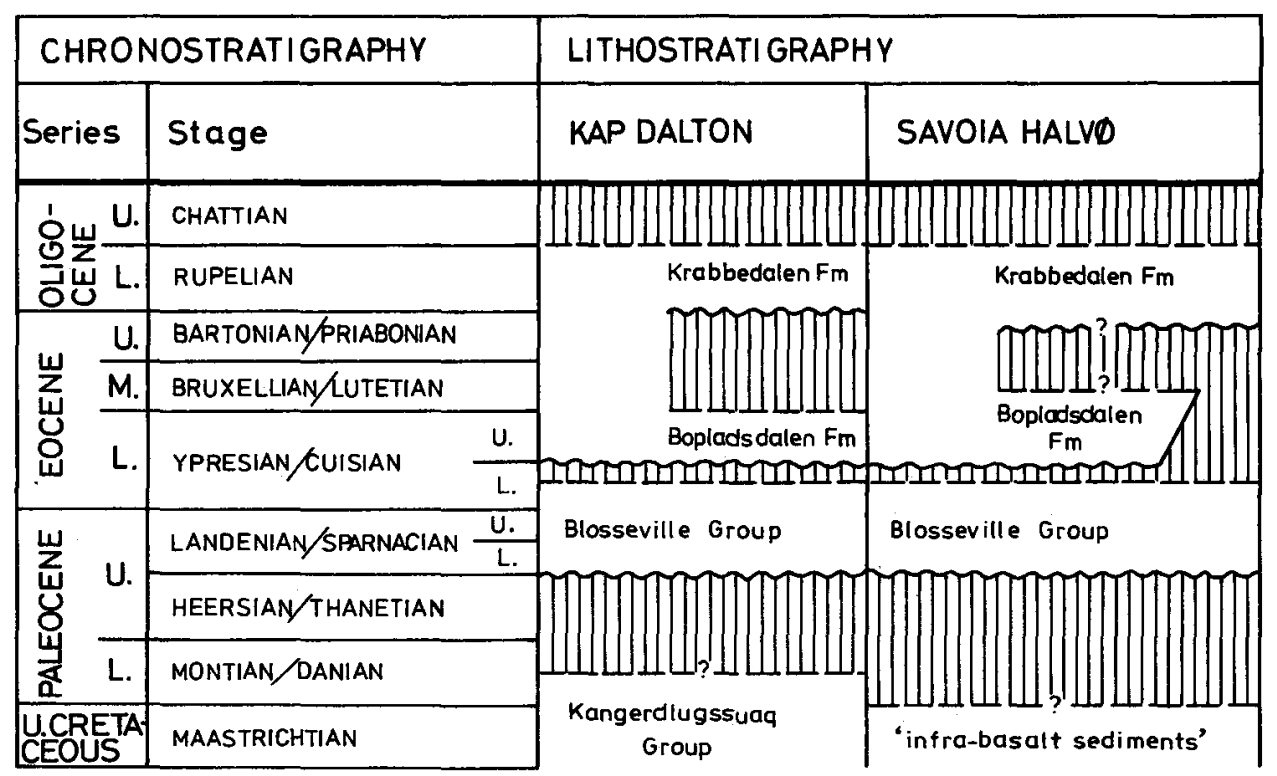

Fig. 20. Paleogene succession of the Blosseville Kyst, East Greenland. Kap Dalton: modified after Soper et al. (1976) and Soper \& Costa (1976). Savoia Halvø: modified after Hassan (1953) and Birkenmajer (1972).

\section{Environment}

The shallow-marine character of the Krabbedalen Formation sediments is well evidenced by its fauna: bivalves, gastropods and crabs (Hassan, 1953). A similar conclusion may be drawn from the occurrence of arenaceous benthos: Saccammina compressa (Cushman \& McCulloch), Reophax subfusiformis Earland, Haplophragmoides advenus Cushman, $\boldsymbol{H}$. columbiensis Cushman and $\boldsymbol{H}$. planissimus Cushman, which occur along the coasts of Alaska at depths not exceeding $30 \mathrm{~m}$ (Cushman \& McCulloch, 1939). Globobulimina pacifica Cushman occurs in Recent seas at 38-40 fathoms (Barker, 1960). Other, predominantly shallow-water forms, are represented by species of the genera Ammobaculites, Saccammina, Trochammina and Haplophragmoides, while Rhabdammina, Bathysiphon and Reophax occur both in shallow and deep-water seas.

A characteristic element of the Krabbedalen Formation foraminiferal assemblage is the presence of several species of the genus Cyclammina whose dimensions markedly exceed those typical for the species. According to Bandy (1960) Cyclammina is typical of cold waters of the middle bathyal zone where its dimensions show a tendency to increase with the depth of the basin. However, Vonderbank (1970) observed comparatively numerous specimens of Cyclammina in shallow-marine Paleocene (Danian-Montian) sediments of Spitsbergen.

The abnormally large dimensions of species of the genus Cyclammina and Reophax pilulifer Brady are also present in the Krabbedalen material and could have been caused by 
very low temperatures of the Eocene-Oligocene coastal waters of the East Greenland shelf. Experiments by Loeblich \& Tappan (1964) on living foraminifers have shown that decrease in the water temperature causes abnormal growth of the last chamber of their tests.

\section{Evidence for the East Greenland Current}

Very low temperatures of the Eocene-Oligocene sea water along the east coast of Greenland, suggested by the present investigation could have been caused by a coastparallel southerly current, analogous to the present East Greenland Current, and likewise born at high latitudes. If so, it might point to the existence of a seaway which connected the Arctic Ocean and the Norwegian-Greenland Sea Basin during the Late Palaeogene.

The date of separation of Norway and Greenland north of Iceland at about 60-70 m.y. (Cretaceous-Tertiary) is suggested by the study of magnetic anomalies on the Reykjanes Ridge (Avery et al., 1968; Vogt et al., 1970), and agrees with the date (60 m.y.) assumed for the separation of the Lomonosov Ridge from the northern margin of Eurasian shelf due to the growth of the Gakkel Ridge in the Arctic Basin (Pitman \& Talwani, 1972; Vogt \& Avery, 1974).

The distribution of marine macrofaunas in the Scandic area points to the existence of the East Greenland Current already from the beginning of the Tertiary (Strauch, 1970, fig. 1).

\section{References}

Avery, O. E., Burton, G. D. \& Heirtzler, J. D. 1968: An aeromagnetic survey of the Norwegian Sea. J. geophys. Res. 73, 4583-4600.

Bandy, O. L. 1960: General correlation of foraminiferal structure with environment. Rep. 21st int. geol. Congr., Norden 22, 7-19.

Barker, R. W. 1960: Taxonomic notes on the species figured by H. B. Brady in his report on the Foraminifera dredged by H. M. S. Challenger during the years 1873-1876. Soc. Econ. Pal. Min., Spec. Publ. 9, 1-115.

Birkenmajer, K. 1972: Report on investigations of Tertiary sediments at Kap Brewster, Scoresby Sund, East Greenland. Rapp. Grønlands geol. Unders. 48, 85-91.

Cushman, J. A. \& McCulloch, I. 1939: A report on some arenaceous Foraminifera. Univ. South Calif. Publ. 6, 1, 113 pp.

Hassan, M. Y. 1953: Tertiary faunas from Kap Brewster, East Greenland. Meddr Grønland 111, 5, 42 pp.

Loeblich, A. R. \& Tappan, H. 1964: Treatise on invertebrate paleontology. C, Protista 2, Sarcodina, chiefly "Thecamoebians" and Foraminifera, 900 pp. In Moore, R. C. (edit.) Geol. Soc. Am. \& Univ. Kansas Press.

Pitman, W. C. III \& Talwani, M. 1972: Sea-floor spreading in the North Atlantic. Bull. geol. Soc. Am. 83, 619-646.

Soper, N. J. \& Costa, L. I. 1976: Palynological evidence for the age of Tertiary basalts and post-basaltic sediments at Kap Dalton, central East Greenland. Rapp. Grønlands geol. Unders. 80, 123-127.

Soper, N. J., Higgins, A. C., Downie, C., Matthews, D. W. \& Brown, P. E. 1976: Late Cretaceous-early Tertiary stratigraphy of the Kangerdlugssuaq area, east Greenland, and the age of opening of the north-east Atlantic. J. geol. Soc. Lond. 132, 85-104.

Strauch, F. 1970: Die Thule-Landbrücke als Wanderweg und Faunenscheide zwischen Atlantik und Skandik im Tertiär. Geol. Rdsch. 60, 381-417. 
Vogt, P. R. \& Avery, O. E. 1974: Tectonic history of the Arctic Basins: partial solutions and unresolved mysteries. In Y. Herman (edit.) Marine geology and oceanography of the Arctic Seas, 83-117. Berlin-Heidelberg-New York: Springer.

Vogt, P. R., Ostenso, N. A. \& Johnson, G. L. 1970: Magnetic and bathymetric data bearing on sea-floor spreading north of Iceland. J. geophys. Res. 75, 903-920.

Vonderbank, K. 1970: Geologie und Fauna der Tertiären Ablagerungen Zentral-Spitzbergens. Norsk Polarinst. Skr. 153, $119 \mathrm{pp}$.

Institute of Geology, Polish Academy of Sciences,

Senacka 3,

31-002 Krakow,

Poland.

\title{
Stratigraphical and sedimentological studies of Triassic rocks in central East Greenland
}

\author{
Lars B. Clemmensen
}

The present study of Triassic rocks in Jameson Land and Scoresby Land and on Traill $\varnothing$ (fig. 21) is a continuation of the field investigation initiated in 1975 (Clemmensen \& Andreasen, 1976). The Danish Natural Science Research Council (SNF) provides funds for the investigation in progress.

The purpose of this note is to present a new lithostratigraphical subdivision of the Triassic rocks (fig. 22) and to interpret the depositional environments of the stratigraphic units.

\section{Jameson Land and Scoresby Land}

The Triassic rocks were studied from five camp sites and several sedimentological logs varying in length from $c .40 \mathrm{~m}$ to more than $1000 \mathrm{~m}$ were measured. Only the upper three formations in the Scoresby Land Group of Perch-Nielsen et al. (1974) will be described.

\section{Pingo Dal Formation}

The formation in Jameson Land and Scoresby Land is subdivided into the Rødstaken (below), the Klitdal and the Paradigmabjerg Members. The Sydkronen Member described as the uppermost member within this formation by Perch-Nielsen et al. (1974) was found to be poorly defined; rocks apparently belonging to this unit are more naturally included in the Paradigmabjerg Member and in the new Kolledalen Member of the Gipsdalen Formation.

As the three lower members of the Pingo Dal Formation are defined in agreement with Perch-Nielsen et al. (1974), they will not be described in detail here. 